\begin{tabular}{|c|c|}
\hline \begin{tabular}{l|l|l|l}
$\mathbf{C}$ & $\mathbf{O}$ & $\mathbf{P}$ & $\mathbf{E}$
\end{tabular} & Turyzm/Tourism \\
\hline $\begin{array}{l}\text { Member since } 2019 \\
\text { JMM } 14487\end{array}$ & $2021,31 / 2$ \\
\hline
\end{tabular}

\title{
A FINE LINE BETWEEN RED AND DARK: ANTI-COMMUNIST FILM-INDUCED TOURISM
}

\author{
Bintang Handayani ${ }^{a}$ iD, Jean Henrique Costa $^{b}$ iD \\ ${ }^{a}$ Universiti Malaysia Kelantan City Campus, Faculty of Hospitality, Tourism, and Wellness; \\ http://orcid.org/0000-0002-3324-7486; e-mail: bintang.handayani@umk.edu.my \\ b State University of Rio Grande do Norte (UERN), Department of Tourism and the Post-Graduation Program in Social \\ and Human Sciences; https://orcid.org/0000-0002-8091-2418; e-mail: prof.jeanhenriquecosta@gmail.com
}

How to cite (APA style): Handayani, B., Costa, J.H. (2021). A fine line between red and dark: Anti-communist film-induced tourism. Turyzm/Tourism, 31 (2), 7-23. https://doi.org/10.18778/0867-5856.31.2.01

\begin{abstract}
This study explores the ' 30 September Movement' that staged a communist coup in 1965 as travel motivation for an anti-communism museum. 'Framing' and 'uses and gratifications' theories were used for this case study. The findings concluded that negative film plots and scenes are signature themes that can be used as attributes of red or dark film motivations for tourism. The use of theories, such as 'framing' and 'uses and gratifications', along with reflexive thematic analysis has provided unique and valuable theoretical insights that may be overlooked by other analyses.
\end{abstract}

\section{KEYWORDS}

anti-communism museums, dark tourism, film-induced tourism, red tourism, Indonesia

\section{ARTICLE INFORMATION DETAILS}

Received:

8 November 2020

Accepted:

13 April 2021

Published:

3 December 2021

\section{INTRODUCTION}

With the ideological tension between so-called western ideology and communism, in Indonesia communism occurred alongside that in the Soviet Union and China. Its ban in Indonesia started in 1965 and was prominently symbolised by the well-known tragic event that involved the assassination of six Indonesian army commanders (seven were in fact targeted) by the Indonesian Communist Party (G30S/PKI) in an abortive coup d'état as part of the ' 30 September Movement'. The film set of G30S/PKI potentially serves as a predictor of dark film-induced tourism, but there has been no evidence of its significance for film-induced tourism.

Various popular dark places, such as the museums of Lubang Buaya and Kesaktian Pancasila in Jakarta, have been developed for educational tourism (edu-tourism), and are regularly visited by Indonesian students with their teachers, and were especially during the 'New Order'. Following the 1998 Indonesian Reformation, everything related to the New Order regime is or appears to be unpopular. As a result, during this time the media and creative industries along with tourism appeared to be less attractive and not in the public interest. Historically, the New Order regime used the tourism industry to develop nationalism and national identity (see Adams, 1998) and although the Pengkhianatan G30S/PKI film was regularly aired on state television (TVRI), after the reformation it stopped and there seems to be limited evidence of people watching the film now (Handayani, 2017; kumparanNEWS, 2017).

In Indonesia, political framing (e.g. political murder) in film-induced and 'dark tourism' is likely to be associated with the history of anti-communism. Handayani (2017) pointed out that films on anticommunism have enriched dark tourism, specifically 
through political framing. Meanwhile, the association of the history of anti-communism in Indonesia and its political framing is considered as a part of 'red tourism' although the definition of red tourism in the western context denotes visits to sites related to the current communist regimes in countries like Cuba, North Korea, and China (Ivanova, Buda, 2020). Research on red tourism and communist identity has been associated with China, whereas red tourism in the South-East Asian region, particularly in Indonesia, has been underresearched ( $\mathrm{Li}, \mathrm{Hu}$, Zhang, 2010) and is specifically addressed here.

Inspired by the huge interest of tourists with a special interest in the wide spectrum of dark and historical sites and the history of a nation (Handayani, 2017), the current study aims to explore travel motivations for visiting Lubang Buaya Museum, which is known as an anticommunism museum, and the Kesaktian Pancasila Monument (Handayani, 2017; kumparanNEWS, 2017). This study exclusively focuses on the following questions: 1. Does viewing the Pengkhianatan G30S/PKI film induce tourism?

2. Would visiting anti-communism museums (induced by a dark film) accommodate the kind of novelty-seeking described as special-interest or dark tourism?

3. Would 'critical thinking' in tourists result?

Following from this it was deemed fitting to examine how dark-film tourism revolves around mass killing, coupled with political issues and national history. A mass grave, especially in relation to a political issue and national history, has been discussed in tourism studies (Adams, 1998; Handayani, 2017; Kami, 2017; kumparanNEWS, 2017). Notably, the 30 September Movement in 1965 is considered one of the $20^{\text {th }}$ century's worst mass killings (Ikhwan, Yulianto, Parahita, 2019). The anti-communism movement in 1965 is considered as a dark chapter in the history of Indonesia. Hence, this fulfils the needs of tourists with a special interest and validates the thirst of thanatourists to visit macabre sites for contemplation and self-reflection.

Pengkhianatan G30S/PKI is an anti-communist film that was broadcast on state television regularly during the New Order and represents evidence of the intertwined relationship of the tourism industry, nationalism and national identity, with media and creative industries. However, the ethical dilemma of transforming a negative film plot, as depicted in Pengkhianatan G30S/PKI, into a public attraction that drives the behavioural intention of film tourists has been understudied. Considering that not only does Pengkhianatan G30S/PKI provide evidence of this intertwined relationship, but also, more importantly, it supports the growth of darker themes (Miles, 2002; Strange, Kempa, 2003), coupled with red tourism and film-induced tourism. In this sense, examining dark film-induced tourism, and an intention to visit the filmed dark places, enriches the existing body of knowledge of special-interest, dark and film-induced tourism (Cardoso, Estevão, Fernandes, Alves, 2017; Handayani, 2017; Kim, Reijnders, 2018; kumparanNEWS, 2017; Sabre, 2017).

Based on these reasons, focusing on film-induced tourism, the theory of framing has been used in the current work to examine the negative film plot (Loureiro, de Araujo, 2015) and how this plot frames dark tourism. Added to this, 'uses and gratifications' theory has also been used to assess intentions to visit dark places in the context of Pengkhianatan G30S/PKI. Reflexive thematic analysis has been undertaken as well.

\section{RELATED LitERATURE}

To date, the intertwined variables of national history, dark tourism attractions, and media-related tourism have been recorded, for example, in the contexts of Thai history and the Second World War (Lennon, 2018). Although film-induced tourism has been in the limelight and provided evidence of visiting intentions, destination images and place attachment (Cardoso, Estevão, Fernandes, Alves, 2017; Hao, Ryan, 2013; Pan, Tsai, Lee, 2011), little attention has been paid to the role of negative film plots that focus on political framing and tragedy in the history of a nation.

According to Lennon (2018), the media can drive tourism and indicate the importance of filmic narratives in the development of urban heritage. For instance, tourism in the settings of political murder, such as the assassination site of the former U.S. President John F. Kennedy in 1963 (Foley, Lennon, 1996), was recorded in the literature of film-induced tourism and within the spectrum of tourists' desire to visit related filming locations (Bencivenga, Chiarullo, Colangelo, 2015). Furthermore, studies on dark-themed film tourism (Çoban, 2018a, 2018b; Loureiro, de Araujo, 2015) have examined dark places in Turkey. On the other hand, research has also suggested that exposure in the media of certain filming locations and their negative portrayal may not increase viewers' intentions to visit them and may stimulate the opposite effect (Beeton, 2016). Nevertheless, media-related tourism resulting from controversial films or negative film plots may have the potential to benefit the tourism industry and serve as an agent of destination image (Loureiro, de Araujo, 2015). In this sense, the existence of museums, the deathbeds, prisons, and other related features depicted in films should be examined in terms of the pull-and-push factors for film tourist visiting intentions and behaviour. 


\section{The FILM PLOT AND 30 SePTEMBer Movement OF THE INDONESIAN COMMUNIST PARTY (G30 S/PKI)}

Seven detachments of troops in trucks dispatched by Lieutenant Colonel Untung Syamsuri (the commander of Tjakrabirawa, the Presidential Guard Unit), which comprised of soldiers from the Presidential Guards (Diponegoro and Brawijaya Divisions), left the movement's base at Halim Perdanakusumah Air Force Base, located to the south of Jakarta, to kidnap seven generals (members of the Army's General Staff). On 1 October 1965 at 03:15, three of the intended targets, specifically Lieutenant General Ahmad Yani (Minister or Commander of the Army), Major General Mas Tirtodarmo Haryono and Brigadier General Donald Isaac Panjaitan, were murdered at their homes, while another three targets, namely Major General Soeprapto, Major General Siswondo Parman and Brigadier General Sutoyo Siswomiharjo, were taken alive to Lubang Buaya (30 September Movement, 2020).

However the main target, General Abdul Haris Nasution (Coordinating Minister for Defence and Security and Armed Forces Chief of Staff), managed to escape the kidnap attempt by jumping over a wall into the garden of the Iraqi embassy. Unfortunately his aide, Lieutenant Pierre Tendean, who was mistaken for General Abdul Haris Nasution in the dark, was captured. General Abdul Haris Nasution's five-year-old daughter, Ade Irma Suryani Nasution, was shot by the assault team and died on 6 October 1965. Additionally, Police Chief Brigadier Karel Sadsuitubun, who was on patrol on that tragic night and responsible for guarding General Abdul Haris Nasution's neighbourhood, was shot and killed. The last victim was Brigadier General Donald Isaac Pandjaitan's nephew, Albert Naiborhu, who was shot during the General's home raid. All of the victims' bodies were taken to Lubang Buaya. Those who were still alive were shot early the following morning with their bodies then thrown into a disused well near the base, which is now known as the Lubang Buaya Museum (30 September Movement, 2020; Festiani, Azizah, Rostiyani, 2012). This tragic history is also remembered on the main roads in Jakarta which are named after the victims. On 1 October 1981, the former President Suharto inaugurated the Kesaktian Pancasila Museum.

\section{HISTORICAL SITES AND HISTORY IN MEDIA-RELATED TOURISM}

Historical or heritage sites revolve around enduring storylines, and dark sites are specifically embedded with the darkest side of the thematic national experience.
Thematic national history has been established in several past studies on media-related tourism, filminduced tourism, and cinematic or media-induced tourism (see Bolan, Boy, Bell, 2011; Cardoso, Estevão, Fernandes, Alves, 2017; Kim, Reijnders, 2018; O'Connor, Flanagan, Gilbert, 2008; Sabre, 2017), while certain past research on travel and tourism has focused on 'contents tourism' (Seaton, Yamamura, 2018). Meanwhile, mediarelated tourism is known as a phenomenon in which tourists travel to specific places associated with novels, films, or television series (Reijnders, 2016). Tourists visiting destinations associated with media-induced tourism, such as film-induced tourism, has supported gastronomic tourism (Viganò, 2003).

To date, research on the nexus of tourism and nation-building has discussed the use of tourism and nation branding as a tool for nationalism (Adams, 1998; Jordan, 2014). For instance, a specific study on tourism in South-East Asia, induced by the blockbuster film "Eat Pray Love", which was partially set in Bali (Adams, 2016), focused on the culinary, spiritual, and emotional dimensions of tourism and identity-shaping. Examining how tourism can be used as a tool to improve a nation's negative image on the global market has also been recorded in literature (Dolezal, Trupp, 2015). In this sense, tourism, nation-building, and special-interest tourism may be attributed to national history, however, the nexus of film-induced tourism, nation-building, and special-interest tourism (e.g. dark tourism) has received limited attention. Hegemonic actors in tourism tend to focus their efforts more on commercially selling tourist destinations than drawing some parallel between the history of those places and the issue of identity. Thus, history that is not commercially saleable is unlikely to be told or turned into a commodity.

Film-induced tourism consumption revolves around involvement and innovation in tourism, where innovation refers to the use of new methods in social, cultural, and administrative environments (Tüzünkan, 2017). For example, cinematic tourism leads to the novelty-seeking tendency of tourists to clarify a national history that is described through the discourse of an ideology depicted in a film (see Pan, Kosicki, 1993). On the other hand, Curtin (2010) studied wildlife tourists and explained travel motivation based on individual-interest tourism which showed how innovation can be identified. In this sense, tourism is about the interactional relationship of emotions, place attachment and the kind of attractions that are differentiated by emotions and symbolism, from the lightest to the darkest experiences (Azevedo, 2017). There has been a growing trend to a new form of consumption where tragedy, death and disaster are the attractions such as visits to museums or death sites (Handayani, Korstanje, 2017). Under late capitalism, even death is turned into a commercial product 
(Costa, 2013). However, how national history frames special-interest tourism, such as dark tourism, filminduced tourism, or 'edu-dark' tourism, has remained underexplored.

Films trigger increased tourist visits to filmed destinations (Beeton, 2016; Bencivenga, Chiarullo, Colangelo, 2015; Croy, 2004). Indeed, they promote the image of a territory and offer a symbolic representation of a place which influences the choices of tourists. Research has also suggested that imaginary landscapes (Loureiro, de Araujo, 2015) and a naturalistic atmosphere (Bencivenga, Chiarullo, Colangelo, 2015) can increase visiting intentions. Accordingly, Macionis (2004) indicated that motivation in film-induced tourism mainly revolves around (1) pull factors, namely filming a place (i.e. location attributes, scenery, landscapes, weather, cultural origin, social origin and activity origin), personality (i.e. casts, characters, and celebrities or stars), and performance (i.e. plot, theme and genre); and (2) push factors, namely internal drive (i.e. egoenhancement, status or prestige, fantasy or escape, vicarious experience and search for self-identity). As limited attention has been given to tourism induced by dark films that contain negative plots (e.g. political tension), negative scenarios, themes and genres are likely to provide a setting that may intertwine with special-interest tourism and dark tourism. In this sense, negative plots and themes, along with a violent film genre, may trigger tourist visits to a particular destination.

Moreover, Loureiro and de Araujo (2015) previously examined the relationship between films and behavioural intentions and this was deemed significant for dark film-induced tourism whereas Tzanelli (2016) discussed how film settings and plots frame a simulation of a fantasy derived from film-induced tourism. This discussion has led to questions of authenticity and the use of films in manufacturing tourist experience. The seminal work on heritage sites as filming locations involved the case of Game of Thrones (Bowyer, 2017); films and television series create strong emotional ties to the depicted areas which present certain activities that visitors and recreationists desire to imitate and experience (Beeton, 2016). Furthermore, devoted film viewers search for specific film locations on the internet where destination image can increase travel motivation (Spears, Josiam, Kinley, Pookulangara, 2013). In view of this, the current study suggests that a filming location can drive visiting intentions, and shape destination image and place attachment while aiming to explore this potentially relevant connection. Additionally, motivation for film-induced tourism, such as novelty, prestige or fantasy (Macionis, Sparks, 2009), is potentially connected to dark film-induced tourism.

\section{RESEARCH DESIGN}

To date, framing analysis has been used in mediarelated tourism (Pan, Santos, Kim, 2016) such as filminduced tourism (see Pan, Kosicki, 1993; Pan, Tsai, Lee, 2011). Although framing analysis is rarely used in tourism studies, the potential use to analyse filminduced tourism has been reviewed and discussed (Pan, Kosicki, 1993; Pan, Tsai, Lee, 2011). Therefore, the theory of framing was used to assess negative film plots in the context of film tourism. Meanwhile, 'uses and gratifications' theory was considered to explain the novelty-seeking among tourists in this study. In particular, it was employed to assess visiting intentions to dark places in the context of Pengkhianatan G30S/ PKI. Additionally, Pengkhianatan G30S/PKI served as a basis for reflexive thematic analysis using the constructive theoretical perspectives of Braun and Clarke (2019).

\section{FRAMING THEORY}

Erving Goffman (1974) introduced framing theory. Focusing on organising individual experiences that emerge as social experiences, framing analysis, which aims to highlight a particular phenomenon as more meaningful, is often used in media studies (Fiske, 1983). Framing analysis underlines a particular event in a particular context, focusing on issues that are highlighted as necessary and exposed to the public. Basically, the media frames a certain phenomenon, presents and exposes it purposefully to the public, and sets an agenda.

\section{USES AND GRATIFICATIONS THEORY}

Uses and gratifications theory has been recorded in the contemporary literature on communication and the proliferation of technology, for example, in social media and tourism reviews (Gan, Wang, 2015; Ho, See-To, 2018). However, the application of this theory in the context of film-induced tourism appears to be limited, even though it can be used to examine how negative film plots and dark scenes motivate film tourism. According to this theory, people can actively meet their needs by selecting and using a particular medium with the aim of gratifying a variety of needs, leading to cognitive, affective and behavioural outcomes (Katz, Blumer, Gurevitch, 1974).

Uses and gratifications theory focuses on what people do with the media, rather than the influence 
of the media on individuals (Katz, Blumer, Gurevitch, 1974). This explains the degree of openness to a new experience that is related to movie attendance and reading pleasure. At the same time, voyeurism and personality seem to be related to selective exposure to media, selective exposure of content and content enjoyment (Krcmar, 2017). Hence, uses and gratifications theory is relevant to the characteristics of thanatourists and special-interest tourists.

Furthermore, research on uses and gratifications theory has shifted its focus from the effects of media to the reasons why audiences watch such programmes (Brown, Lauricella, Douai, Zaidi, 2012; Doyle, 2006; Rubin, 1993). Uses and gratifications theory is suitable for exploring why individuals choose to use a film viewing to gratify film tourist behaviour. Information or curiosity, identification, social interaction and entertainment are considered appropriate for the testing of gratification. In communication studies, uses and gratifications theory has been used to explore why individuals find crime dramas so appealing. Previous studies on motivations for film consumption, adapted from communication studies, suggested variables of age, gender and film viewing frequency. Furthermore, research has also suggested that high sensation-seeking predicts an attraction towards violent television and internet viewing (Krcmar, Greene, 1999; Slater, 2003), while sensation-seeking gives rise to passing time and escapism as motivations for television viewing (Conway, Rubin, 1991). In this vein, Brown et al. (2012) suggested that television viewing can predict a fuller gratification and this provided the basis for the present study in the context of dark film-induced tourism.

In addition, it is not possible to insist on cultural research models that unilaterally recognize the influence of the media over individuals without acknowledging the uses and readings made by the media viewers themselves. In this sense, cultural studies has also deepened the reflective role of consumers when they experience or consume a particular cultural practice (Costa, 2012b). Therefore, the readings that individuals make of media products are not always made according to the interests of economic actors. Individuals make readings of opposition and negotiation too, according to Stuart Hall's perspective (Costa, 2012a). In addition, the cultural consumption of a tourist destination or filmic cultural experience that is stimulated by cinema is not something inborn or natural. Therefore, how a film influences interest in visiting a place of death or pain depends on how the individual behaves critically in the mass media and the level of cultural capital.

Stafford and Stafford (1996) noted the following types of gratification: (1) content; (2) process; and (3) social. In particular, content gratification is related to the message itself, while process gratification is related to the communication process. In this vein, content gratification refers to the fulfilment of information expectations which consist of information-related factors such as information seeking and information sharing. Social gratification, on the other hand, refers to communication with others. Content gratification was considered the most appropriate for the current study because of its framing purpose. Moreover, this matched the second objective which focused on how film viewing drives film-tourist behaviour as a basis for conceptualising how negative film plots and scenes are a part of film-induced and dark tourism. Uses and gratifications theory in this context is likely to support a particular interest in tourism suggesting a tendency of tourists to pursue novelty-seeking during site visiting.

\section{REFLEXIVE THEMATIC ANALYSIS}

The use of thematic analysis is encouraged for tourism studies (Walters, 2016) and reflexive thematic analysis aims to study the meaning and construction of social situations through specific themes (Braun, Clarke, 2019). Computer-assisted qualitative data analysis software was not used given the importance of deep reflection in thematic analysis and the role of the researcher's subjectivity in its qualitative paradigm (Braun, Clarke, 2019). For that reason, an active viewing of the Pengkhianatan G30S/PKI film was made instead. The analysis focused on the constructivism of the darkthemed film itself and the dark historical sites in the negative film plot were examined according to its underlying concept and shared meanings in order to explore the phenomenon in depth and within its reallife context (Yin, 2013).

Reflexivity in thematic analysis suggests the crucial role played by the researcher to generate relevant themes and the central social meaning of the explored issues (Braun, Clarke, 2019). The use of this approach aims to identify themes within socio-cultural and ideological contexts. The procedures of thematic analysis reflect the qualitative paradigm and focus on the researcher's subjectivity not a theoretical approach (Braun, Clarke, 2019). The researcher's subjectivity includes analysis based on organic and recursive coding processes as well as the importance of deep reflection and engagement with data (Braun, Clarke, 2019). The 'coder's' subjectivity, which includes theoretical sensitivities, interests and experiences, acts as a filter in thematic analysis. Thus, the outcomes of the analysis are considered as ongoing revisions, rather than a finalised version (McAllum, Fox, Simpson, Unson, 2019).

Dark-themed film tourism and the dark historical sites found in negative film plots develop from past 
studies to employ a deductive approach and this was also considered for this study. Focusing on the central meaning-based concept of dark-themed film tourism and the dark historical sites in negative film plots, relevant themes were generated for dark film-induced tourism in relation to visiting intentions. In this case, the thematic analysis explicitly indicated the steps taken by a researcher as a filter in the familiarisation of film attributes, coding, revisions and the generation of themes. The film attributes examined included the those of location, scenery, landscape, weather, cultural origin, social origin, activity origin, casts, characters, celebrities or stars, plot, theme and genre.

\section{FINDINGS}

As discussed in the reviewed literature (see $\mathrm{O}^{\prime}$ Connor, Flanagan, Gilbert, 2008), the obtained findings can be used to map the signature story and brand of anticommunism museums and historical sites such as Lubang Buaya and Kesaktian Pancasila. Overall, the findings suggest that film viewing does gratify needs, provokes motives that affect media use and leads to cognitive, affective and behavioural outcomes. Viewing negative film plots and scenes drives film tourist behaviour where such plots and scenes serve as attributes to motivate film tourism. Therefore, this study suggests viewing these in Pengkhianatan G30S/PKI as layers of film-induced and dark tourism, with anti-communism museums and historical sites in Indonesia as a layer in red tourism in SouthEast Asia.

From the analysis, the central meaning-based concept of Pengkhianatan G30S/PKI involved a dark-themed film and negative film plots with political framing and tragedy in the history of the nation. Negatively portrayed filmed locations attract tourists who are into dark tourism and enrich the layers of both filminduced and red tourism. Besides this, the involvement of national history in red film-induced tourism and edu-tourism can be labelled as 'edu-dark' tourism or in other words, a visit to hostile filming locations that contain specific elements of a film plot attributed to the darkness of national history, with a focus on political framing and national tragedy. This goes beyond the political discourse and focuses on accommodating novelty-seeking tourists. As discussed by Costa and Korstanje (2016), this novelty may reveal in fact a respectful and critical attitude to the past or, on the contrary, an alienated posture, or even providing an example of sadistic behaviour.

As depicted in Tables 1 and 2, themes generated from Pengkhianatan G30S/PKI can be used as attributes for dark film-induced tourism. In this case, the dark historical sites in negative film plots are located at Lubang Buaya, in which anti-communism museums and historical sites have emerged. Meanwhile, the 30 September Movement remains a tragedy that also involved anti-communism in the history of Indonesia, followed by the storylines of the deaths of the six generals. These attributes of dark film-induced tourism, specifically the political framing, the tragedy on 30 Sep-

Table 1 . The coding process for dark film-induced tourism

\begin{tabular}{|l|l|l|}
\hline \multicolumn{1}{|c|}{ Meaning units from raw data } & \multicolumn{1}{|c|}{ First-level codes } & \multicolumn{1}{c|}{ Category of themes } \\
\hline The communist coup in 1965 & Plots of political framing & $\begin{array}{l}\text { Negative film plots } \\
\text { Framing red tourism for dark sites }\end{array}$ \\
\hline 30 September Movement & The tragedy & The history of a nation \\
\hline Lubang Buaya and Kesaktian Pancasila & Dark places and dark historical sites & Anti-communism museums and historical sites \\
\hline $\begin{array}{l}\text { Seven generals kidnapped } \\
\text { and murdered }\end{array}$ & $\begin{array}{l}\text { Storylines } \\
\text { Filming locations }\end{array}$ & $\begin{array}{l}\text { 'Edu-dark' tourism } \\
\text { Film or media-related tourism }\end{array}$ \\
\hline
\end{tabular}

Source: authors.

Table 2. Defining themes for dark film-induced tourism

\begin{tabular}{|l|l|}
\hline \multicolumn{1}{|c|}{ Themes } & \multicolumn{1}{c|}{ Description of themes } \\
\hline $\begin{array}{l}\text { Negative film plots } \\
\text { Framing red tourism for dark sites }\end{array}$ & $\begin{array}{l}\text { Ideological contexts, sadism, mass killing and the murder of the six generals and their } \\
\text { family members }\end{array}$ \\
\hline The history of a nation & Political agenda and anti-communism movement \\
\hline $\begin{array}{l}\text { Anti-communism museums } \\
\text { and historical sites }\end{array}$ & The glory of the heroes, the status quo and the beginning of the new era in Indonesia \\
\hline $\begin{array}{l}\text { 'Edu-dark' tourism } \\
\text { Film or media-related tourism }\end{array}$ & $\begin{array}{l}\text { Fascination with the death of the six generals, dark history, the tragedy of a nation in dark } \\
\text { places, and dark historical sites can be learned through dark film-induced tourism }\end{array}$ \\
\hline
\end{tabular}

Source: authors. 
tember 1965, and the storylines can be proposed as 'edudark' tourism.

The fascination with the death of politicians, VIPs, celebrities and other public figures is not only encouraged by the media but is also used by tourism bodies and authorities as part of media-induced tourism. A tragic event highlights the place of death as a potential tourist attraction. Unsurprisingly, Beeton (2016) suggested that film-induced tourism, as a backdrop to the action and the hostile environment depicted, contains a level of emotional attachment. In a sense, this kind of visit aims to be an authentic experience which is commonly labelled as 'reality tourism' and 'vacation dedication' (Ring, Yanamandram, Gretzel, Dolnicar, 2019). Reality tourism is likely to involve cultural tours based on altruism including visiting macabre sites (Foley, Lennon, 1996; Freire-Medeiros, 2009). In dark film-induced tourism, negative plots, themes and genres are the main commodities depicted and may also be included in reality tours, as well as confirming the reason why individuals choose to use film viewing as gratification. G30S/PKI revolves around a political tension between the communist movement and national history which leads to questioning the relevance of visiting the highlighted dark places in the film, namely Lubang Buaya Museum and Kesaktian Pancasila Museum. Framing theory in this study identifies the negative film plot in the context of film tourism, and how the dark sites were framed relative to the history of communism. Communism in Indonesia was framed by including the historical sites depicted in the film and other relevant landmark sites, such as Patung Tugu Tani.

The issues exposed at specific filming locations may not increase viewers' visiting intentions but may stimulate the opposite effect. Negatively portrayed filming locations or negative film plots may trigger viewers' intentions not to visit. These aspects may also clarify the historical events on the mediation effect of a film in the framing of a national history, as clarified in the work of Pan and Kosicki (1993). This explains the growing phenomenon of film-induced red tourism, along with current state-of-the-art, dark tourism which stimulates tourists' intentions to visit macabre sites where a mass murder has occurred. Film-viewing behaviour is vulnerable and driven by media, and such gratification fulfils the thirst for novelty-seeking in tourism. It also explains how history is constructed by power and authority with films being used to develop national history and develop the tourism sites depicted in films.

New forms of consumption that involve tragedy, death and disaster are commodities for exchange and open up the possibility of reliving the experience depicted in films which relates to the critical-thinking aspect of special-interest tourism and thanatourism.
In this way, visiting the heroic death sites described in a film and reliving the depicted experiences stimulates the critical-thinking aspect of special-interest tourism. It accommodates the urge of dark tourists for contemplation and self-reflection. Relevant studies have described dark tourism as ego-enhancing, as watching the tragedy of others stimulates a feeling of being more privileged. As films that specifically contain dark or negative plots potentially drive visiting behaviour, the constructed national history can enrich layers of specialinterest and dark tourism.

\section{CONCLUSION AND RECOMMENDATIONS FOR FUTURE RESEARCH}

The case study in this paper highlights the intersection of death and film-induced tourism and paved the way for an in-depth philosophical discussion of how darkthemed films derived from the political framing of a nation can stimulate tourism. It has provided evidence for the stakeholders of film-induced tourism to highlight the natural scenery, landscapes and heritage sites which serve as drivers or backdrops to film-induced tourism, and its dark themes of political framing, mass murder and assassination, for the development of niche tourist markets and special-interest tourism. Besides these, it has also provided evidence of novelty-seeking tourists, suggesting that death seekers and thanatourists explore the 'bright side' of darkness. The negative film plot and political framing in the context of filminduced tourism were audience-centred. Exposure to a heroic death, coupled with political framing, appears to present a phenomenon that constructs the shared values of tourists. The search for an 'end' can lead dark tourists into a more meaningful personal life.

Following from this it is recommended that current film-viewing behaviour and its negative associations with political film plots as predictors of the behaviour of film tourists and film viewing, film tourism motivations and the travel behaviour and demographic profile of dark film-induced tourists, be considered for future research. The effects of 'consumption' motivation for dark-themed film viewing for gratification (information or curiosity, identification, social interaction and entertainment), via age, gender and frequency of film viewing, should also be examined in order to show how these variables influence red (or dark) tourists' visits to historical or heritage sites such as anti-communism museums. Apart from this, exploration of the influence of 'vacation dedication' on visiting anti-communism museums, such as Lubang Buaya Museum and Kesaktian Pancasila Museum, is recommended.

Addressing the three questions raised in this work, a film may act as an inducer of tourist demand 
but we cannot establish a positivist cause-and-effect relationship. Tourist demand is heterogeneous, dynamic, and highly stratified from an emotional point of view. Studies have noted an intense and creative relationship between tourist demand and film production sites. However, some research has shown the limit of such an impact. As for the issue of anti-communism 'accommodating' a special interest in dark tourism, we infer that, with the political resurgence of the extreme right in some countries, paranoia against socialism can be a motivating factor to visit an anti-communism museum in Indonesia. Finally, we cannot conclude whether critical thinking exists in tourists since such an anti-communist film context involves ultranationalist and extremist ideologies far more than libertarian and emancipated thought.

\title{
CIENKA LINIA MIĘDZY CZERWIENIĄ A MROKIEM: ANTYKOMUNISTYCZNA TURYSTYKA FILMOWA
}

\author{
Bintang Handayania ${ }^{(D}$, Jean Henrique Costa ${ }^{b}$
}

\footnotetext{
a Uniwersytet Malezyjski w Kelantanie, Wydział Turystyki, Hotelarstwa i Zdrowia; http://orcid.org/0000-0002-3324-7486; e-mail: bintang.handayani@umk.edu.my

${ }^{\mathrm{b}}$ Uniwersytet Stanowy w Rio Grande do Norte (UERN), Katedra Turystyki, Studium Doktoranckie Nauk Społecznych i Humanistycznych; https://orcid.org/0000-0002-8091-2418; e-mail: prof.jeanhenriquecosta@gmail.com
}

Sposób cytowania (styl APA): Handayani, B., Costa, J.H. (2021). A fine line between red and dark: Anti-communist film-induced tourism. Turyzm/Tourism, 31 (2), 7-23. https://doi.org/10.18778/0867-5856.31.2.01

\begin{abstract}
ABSTRAKT
W niniejszej pracy został zgłębiony temat Ruchu 30 Września - ruchu politycznego odpowiedzialnego za nieudaną próbę komunistycznego zamachu stanu w $1965 \mathrm{r}$. - jako bodźca do zwiedzania muzeów antykomunistycznych. W analizowanym studium przypadku wykorzystano teorię ramową oraz użytkowania i korzyści. Wyniki badania pozwoliły autorom dojść do wniosku, że negatywne fabuły i sceny filmowe mogą zostać wykorzystane jako czynniki motywujące do podejmowania czerwonej lub mrocznej turystyki filmowej. Odwołanie się do takich teorii, jak teoria ramowa czy teoria użytkowania i gratyfikacji wraz z refleksyjną analizą tematyczną, zapewniło możliwość poczynienia unikatowych i wartościowych obserwacji teoretycznych, które mogły zostać pominięte $w$ innych opracowaniach.
\end{abstract}

\section{SŁOWA KLUCZOWE}

muzea antykomunistyczne, mroczna turystyka (dark tourism), turystyka filmowa, czerwona turystyka, Indonezja

\section{INFORMACJE O ARTYKULE}

Przyjęto:

8 listopada $2020 \mathrm{r}$.

Zaakceptowano:

13 kwietnia $2021 \mathrm{r}$.

Opublikowano:

3 grudnia $2021 \mathrm{r}$.

\section{WSTĘP}

Komunizm pojawił się $\mathrm{w}$ Indonezji $\mathrm{w}$ tym samym czasie co w Związku Radzieckim i w Chinach, wraz ze wzrostem napięcia pomiędzy tą doktryną a tzw. ideologią Zachodu. Komunizm został zakazany w Indonezji w 1965 r., co w sposób najbardziej wyrazisty symbolizują dobrze znane $\mathrm{w}$ tym kraju tragiczne wydarzenia, które pociągnęły za sobą zabójstwo sześciu indonezyjskich dowódców wojskowych (celem było siedem osób) przez Komunistyczną Partię Indonezji (G30S/PKI) w ramach nieudanego zamachu stanu, przeprowadzonego przez Ruch 30 Września. Plan filmowy fabularyzowanego dokumentu G30S/PKI stanowi potencjalny czynnik rozwoju turystyki filmowej, jednak jak dotąd nie udowodniono, że ma on wpływ na tę kwestię.

Liczne popularne miejsca związane z mroczną turystyką (dark tourism), takie jak muzea Lubang Buaya i Kesaktian Pancasila w Dżakarcie, powstały ze względów edukacyjnych (turystyka edukacyjna) i od początku były regularnie odwiedzane przez indonezyjskie wycieczki szkolne, szczególnie w czasach tzw. Nowego Ładu. Po przeprowadzeniu reform w Indonezji w $1998 \mathrm{r}$. wszystko, co związane z reżimem Nowego Ładu, było niepopularne lub takie się wydawało. $W$ rezultacie 
$\mathrm{w}$ tamtym czasie przemysł medialny i sektor kreatywny, podobnie jak turystyka, były uznawane za niezbyt atrakcyjne i nie cieszyły się dużym zainteresowaniem społecznym. Historycznie rzecz ujmując, reżim Nowego Ładu wykorzystywał branżę turystyczną do rozwijania ideologii nacjonalistycznej oraz tożsamości narodowej (zob. Adams, 1998). Film Pengkhianatan G30S/PKI był regularnie emitowany w telewizji państwowej (TVRI). Po reformach zaprzestano wprawdzie jego wyświetlania, ale istnieją ograniczone dowody, że ludzie nadal go oglądają (Handayani, 2017; kumparanNEWS, 2017).

W Indonezji realia polityczne ${ }^{1}$ ( $\mathrm{w}$ tym morderstwa na tle politycznym) w turystyce filmowej i mrocznej są najczęściej kojarzone $\mathrm{z}$ historią antykomunizmu. Handayani (2017) zauważa, że filmy o tematyce antykomunistycznej wpłynęły na rozwój mrocznej turystyki, w szczególności właśnie dzięki uwzględnieniu kontekstu politycznego. Tymczasem związek pomiędzy historią antykomunizmu w Indonezji a jej tłem politycznym uważa się za element czerwonej turystyki, która jak wynika z definicji przyjętej na Zachodzie, obejmuje podróże do miejsc związanych z obecnymi reżimami komunistycznymi w takich krajach, jak: Kuba, Korea Północna i Chiny (Ivanova, Buda, 2020). Studia prowadzone nad tematyką czerwonej turystyki i tożsamości komunistycznej wiążą się głównie z Chinami, natomiast ten rodzaj turystyki $\mathrm{w}$ rejonie południowo-wschodniej Azji, zwłaszcza w Indonezji, nie został dotychczas wystarczająco zbadany (Li, Hu, Zhang, 2010). W związku z tym autorzy niniejszego artykułu postanowili szczegółowo omówić wskazane zagadnienie.

Niniejsza praca, zainspirowana ogromnym zainteresowaniem turystów szerokim spektrum miejsc mrocznych i historycznych oraz historią narodową (Handayani, 2017), ma na celu poznanie motywacji turystów do zwiedzania antykomunistycznego Muzeum Lubang Buaya oraz pomnika Kesaktian Pancasila (Handayani, 2017; kumparanNEWS, 2017). Autorzy artykułu skupili się wyłącznie na znalezieniu odpowiedzi na następujące pytania: 1. Czy oglądanie filmu Pengkhianatan G30S/PKI wpływa na rozwój turystyki filmowej?

2. Czy poszukiwanie nowych atrakcji, nazywane turystyką specjalnych zainteresowań bądź mroczną turystyką (dark tourism), wpisuje się w zwiedzanie muzeów antykomunistycznych (spowodowane obejrzeniem mrocznych filmów)?

3. Czy w rezultacie turyści zaczynają myśleć krytycznie?

W związku z tym za stosowne uznano zbadanie, jak mroczna turystyka filmowa ogniskuje się wokół masowych mordów $\mathrm{w}$ połączeniu $\mathrm{z}$ kwestiami politycznymi oraz historią narodową. Zagadnienie masowych mordów, zwłaszcza w odniesieniu do kwestii politycznych i historii narodowej, zostało już omówione przez badaczy turystyki (Adams, 1998; Handayani, 2017; Kami, 2017; kumparanNEWS, 2017). Naukowcy dużo uwagi poświęcili przede wszystkim działaniom
Ruchu 30 Września z 1965 r., uznawanych za jedno $\mathrm{z}$ najokrutniejszych tego typu wydarzeń $\mathrm{w}$ XX w. (Ikhwan, Yulianto, Parahita, 2019). Istnienie ruchu antykomunistycznego w 1965 r. uważa się za mroczny rozdział w historii Indonezji, który zaspokaja potrzeby podróżnych o szczególnych zainteresowaniach i w pewien sposób uzasadnia pragnienie tanatoturystów, by zwiedzać makabryczne miejsca w celu kontemplacji i autorefleksji.

Pengkhianatan G30S/PKI jest filmem antykomunistycznym, który emitowano regularnie w telewizji państwowej w czasach Nowego Ładu. Produkcja ta stanowi dowód na ścisły związek branży turystycznej, nacjonalizmu i tożsamości narodowej z przemysłem medialnym i sektorem kreatywnym. Jednakże dylemat etyczny związany z przekształceniem negatywnej fabuły przedstawionej w Pengkhianatan G30S/PKI w publiczną atrakcję, która wywołuje określone zachowania turystów filmowych, nie został jak dotąd dostatecznie zbadany. Zwłaszcza biorąc pod uwagę fakt, że film ten nie tylko dostarcza dowodów na istnienie opisanego tu ścisłego związku, ale także - co ważniejsze - wzmacnia znaczenie mrocznych tematów (Miles, 2002; Strange, Kempa, 2003) w powiązaniu z turystyką czerwoną i filmową. W tym sensie analiza mrocznej turystyki filmowej i chęć zwiedzania sfilmowanych mrocznych miejsc wzbogaca istniejący zasób wiedzy na temat turystyki specjalnych zainteresowań, mrocznej czy filmowej (Cardoso, Estevão, Fernandes, Alves, 2017; Handayani, 2017; Kim, Reijnders, 2018; kumparanNEWS, 2017; Sabre, 2017).

Biorąc pod uwage wymienione powody, autorzy niniejszej pracy wykorzystali teorię ramową (framing theory) do analizy negatywnej fabuły filmu (Loureiro, de Araujo, 2015) oraz sposobu, w jaki wpływa ona na mroczną turystykę. Dodatkowo odwołali się do teorii użytkowania i gratyfikacji w celu oceny intencji zwiedzania mrocznych miejsc w kontekście filmu Pengkhianatan G30S/PKI. Autorzy przeprowadzili także refleksyjną analizę tematyczną.

\section{PoWIAZZANA LITERATURA}

Dotychczas ściśle powiązane ze sobą zmienne: historia narodowa, mroczne atrakcje turystyczne oraz turystyka medialna, zostały omówione np. w kontekście historii Tajlandii i II wojny światowej (Lennon, 2018). Chociaż turystyka filmowa od jakiegoś czasu znajduje się w centrum zainteresowania naukowców i stanowi wyjaśnienie przyczyn zwiedzania pewnych miejsc, wyobrażenia o nich oraz przywiązania do danej lokalizacji (Cardoso, Estevão, Fernandes, Alves, 2017; Hao, Ryan, 2013; Pan, Tsai, Lee, 2011), niewiele uwagi poświęcono roli negatywnych fabuł filmowych, które koncentrują 
się na kontekście politycznym oraz tragediach wpisanych w historię danego narodu.

Według Lennona (2018) media mogą wpływać na rozwój turystyki i wskazywać na wagę narracji filmowych w rozwoju miejskiego dziedzictwa. Egzemplifikacją mogą być podróże do miejsc zabójstw na tle politycznym, takich jak zamach na byłego prezydenta USA Johna F. Kennedy'ego w 1963 r. (Foley, Lennon, 1996), które zostały odnotowane w opracowaniach na temat turystyki filmowej w ramach spektrum pragnień turystów, by zwiedzać związane z nimi plenery filmowe (Bencivenga, Chiarullo, Colangelo, 2015). Ponadto istnieją badania nad turystyką związaną z dramatami filmowymi, które opisują mroczne miejsca w Turcji (Çoban, 2018a, 2018b; Loureiro, de Araujo, 2015). Inne wyniki badań naukowych sugeruja że nagłośnienie przez media problematyki pewnych plenerów filmowych oraz ukazanie ich w negatywnym świetle może nie zwiększać chęci turystów do odwiedzenia tych miejsc, a nawet przynieść odwrotny skutek (Beeton, 2016). Niemniej jednak podróżowanie $\mathrm{w}$ ramach turystyki medialnej, wynikające z zainteresowania kontrowersyjnymi filmami bądź negatywnymi fabułami filmowymi, może potencjalnie korzystnie oddziaływać na branżę turystyczną i służyć jako narzędzie do promocji wizerunku danego regionu docelowego (Loureiro, de Araujo, 2015). W tym sensie istnienie muzeów, łóż śmierci, więzień oraz innych tego typu lokacji przedstawianych w filmach powinno zostać przeanalizowane pod kątem czynników push i pull dla intencji i zachowań turysty filmowego.

\section{FABUŁA FILMU I RUCH 30 WRZEŚNIA KOMUNISTYCZNEJ PARTII INDONEZJI (G3O S/PKI)}

W nocy 1 października 1965 r. siedem oddziałów wojska w ciężarówkach wyruszyło z kwatery Ruchu w bazie lotniczej Halim Perdanakusumah, zlokalizowanej na południe od Dżakarty, w celu porwania siedmiu generałów (członków sztabu generalnego Armii). W wyprawie brali udział żołnierze Tjakrabirawy, jednostki gwardii prezydenckiej (dokładnie z dywizji Diponegoro oraz Brawijaya), wyekspediowani przez dowódcę tej jednostki - podpułkownika Untunga Syamsuriego.

O godzinie 3.15 trzy z zamierzonych celów, tj. generał broni Ahmad Yani (minister wojny i dowódca armii), generał major Mas Tirtodarmo Haryono oraz generał brygady Donald Isaac Panjaitan, zostali zamordowani w swoich domach, podczas gdy kolejne trzy osoby: generał major Soeprapto, generał major Siswondo Parman oraz generał brygady Sutoyo Siswomiharjo, zostały pojmane i przewiezione do Lubang Buaya (30 September Movement, 2020).

Jednakże głównemu celowi zamachu, generałowi Abdulowi Harisowi Nasutionowi (pełniącemu funkcję koordynującego ministra obrony i bezpieczeństwa narodowego oraz szefa sztabu sił zbrojnych) udało się uniknąć porwania dzięki temu, że przeskoczył przez płot na teren ogrodu ambasady irackiej. Schwytano jednak jego asystenta, porucznika Pierre'a Tendeana, który w ciemności omyłkowo został wzięty za swojego przełożonego. Pięcioletnia córka generała, Ade Irma Suryani Nasution, została postrzelona przez grupę szturmową i zmarła 6 października 1965 r. Ponadto śmiertelny postrzał otrzymał komisarz policji, brygadier Karel Sadsuitubun, odpowiedzialny owej tragicznej nocy za patrolowanie i ochronę osiedla, na którym mieszkał generał Abdul Haris Nasution. Ostatnią ofiarą Ruchu był siostrzeniec generała brygady Donalda Isaaca Pandjaitana, Albert Naiborhu, którego zastrzelono w trakcie ataku na dom jego wuja. Ciała wszystkich ofiar zostały przetransportowane do Lubang Buaya. Tych, którzy jeszcze żyli, zastrzelono wcześnie rano następnego dnia, ich zwłoki zaś wrzucono do nieużywanej studni nieopodal bazy, która dziś jest znana jako Muzeum Lubang Buaya (30 September Movement, 2020; Festiani, Azizah, Rostiyani, 2012). Ta tragiczna historia została również upamiętniona poprzez nadanie głównym ulicom Dżakarty nazw utworzonych od imion i nazwisk ofiar. W szesnastą rocznicę tych wydarzeń, 1 października 1981 r., były prezydent Suharto dokonał uroczystego otwarcia Muzeum Kesaktian Pancasila.

\section{MIEJSCA HISTORYCZNE I HISTORIA W TURYSTYCE MEDIALNEJ}

Miejsca historyczne (dziedzictwa) związane są z ważnymi dla danego narodu wydarzeniami, mroczne miejsca zaś są głęboko wpisane w najtragiczniejsze doświadczenia narodowe. Tematyka historii narodowej została ugruntowana dzięki kilku pracom badawczym na temat turystyki medialnej, filmowej i kinowej (zob. Bolan, Boy, Bell, 2011; Cardoso, Estevão, Fernandes, Alves, 2017; Kim, Reijnders, 2018; O'Connor, Flanagan, Gilbert, 2008; Sabre, 2017), a niektóre badania prowadzone nad podróżowaniem i turystyką dotyczyły „,turystyki treści” („contents tourism”) (Seaton, Yamamura, 2018). $\mathrm{Z}$ kolei fenomen podróżowania turystów do konkretnych miejsc związanych z powieściami, filmami czy serialami telewizyjnymi znany jest jako turystyka medialna (Reijnders, 2016). Turyści przybywający do regionów docelowych związanych z turystyką medialna, w tym z turystyką filmowa, wspierają także turystykę gastronomiczną (Viganò, 2003).

Dotychczas w badaniach nad siecią powiązań między turystyką a kształtowaniem narodu omówiono wykorzystanie turystyki oraz brandingu narodowego jako narzędzi nacjonalizmu (Adams, 1998; Jordan, 2014). Na przykład szczegółowe badanie wyjazdów 
turystycznych do Azji Południowo-Wschodniej, zainspirowanych przebojem kinowym Jedz, módl się, kochaj, którego akcja rozgrywa się częściowo na Bali (Adams, 2016), było skoncentrowane na wymiarze kulinarnym, duchowym i emocjonalnym turystyki oraz kształtowaniu tożsamości. Przeprowadzono również badania dotyczące roli turystyki jako narzędzia służącego do poprawy negatywnego wizerunku nacji na rynku globalnym (Dolezal, Trupp, 2015). W tym sensie turystykę (także turystykę specjalnych zainteresowań, np. mroczną turystykę) oraz kształtowanie narodu można przypisać polityce historycznej ${ }^{2}$, jednak sieć powiązań między nimi nie cieszyła się nigdy szczególnym zainteresowaniem. Hegemoni w branży turystycznej zazwyczaj skupiają swoje wysiłki na komercyjnej sprzedaży destynacji turystycznych, a nie na wskazywaniu związków między historią miejsca a kwestią tożsamości. Dlatego jest mało prawdopodobne, by historia, która nie nadaje się do sprzedaży, została opowiedziana lub przekształcona w towar.

Konsumpcja związana z turystyką filmową koncentruje się wokół zaangażowania i innowacji, oznaczających użycie nowych metod w środowisku społecznym, kulturowym i administracyjnym (Tüzünkan, 2017). Na przykład turystyka kinowa prowadzi do nasilania się tendencji do poszukiwania atrakcji przez turystów, nakierowanego na wyjaśnienie zawiłości historii narodowej, opisanej poprzez dyskurs ideologiczny filmu (zob. Pan, Kosicki, 1993). Z kolei Curtin (2010) zajęła się badaniem turystyki przyrodniczej i wyjaśniła motywację do podróżowania w ramach turystyki indywidualnych zainteresowań, co pokazało, jak można zidentyfikować innowacje. W tym sensie $\mathrm{w}$ turystyce chodzi o związek wzajemnych interakcji między emocjami, przywiązaniem do miejsca oraz różnymi rodzajami atrakcji rozróżnianych poprzez emocje i symbolikę, od doświadczeń najłagodniejszych po najbardziej mroczne (Azevedo, 2017). Obecnie można zaobserwować wzrost zainteresowania nową formą konsumpcji, w której tragedia, śmierć i katastrofy przyciągają ludzi do takich atrakcji turystycznych, jak muzea czy miejsca śmierci (Handayani, Korstanje, 2017). W okresie późnego kapitalizmu nawet śmierć została przekształcona w produkt komercyjny (Costa, 2013). Jednak sposób, w jaki polityka historyczna kształtuje turystykę specjalnych zainteresowań, w tym mroczną turystykę, turystykę filmową czy mroczną turystykę edukacyjna, pozostaje niedostatecznie zbadany.

Filmy wywołują zwiększony ruch turystyczny do miejsc, które zostały w nich uwiecznione (Beeton, 2016; Bencivenga, Chiarullo, Colangelo, 2015; Croy, 2004). Dzieje się tak, ponieważ produkcje filmowe kreują wizerunek danego terytorium, a przedstawione $\mathrm{w}$ nich miejsca są ukazywane w sposób symboliczny, co wpływa na wybory dokonywane przez turystów. Wyniki badań sugerują również, że wyimaginowane krajobrazy
(Loureiro, de Araujo, 2015) oraz naturalistyczna atmosfera (Bencivenga, Chiarullo, Colangelo, 2015) mogą zwiększyć liczbę odwiedzin. Zgodnie z tym Macionis (2004) wskazała, że motywacje w turystyce filmowej koncentrują się głównie wokół:

- czynników pull, czyli filmowania danego miejsca (tj. atrybutów pleneru filmowego, scenerii, krajobrazów, pogody, pochodzenia kulturowego, społecznego oraz aktywności), osobowości (tj. obsady, bohaterówicelebrytów czy gwiazd) oraz wykonania(tj.fabuły, stylu i gatunku);

- czynników push, czylipopędów wewnętrznych(ti.zwiększenia ego, statusu czy prestiżu, zachcianek bądź chęci ucieczki, doświadczeń zastępczych oraz poszukiwania własnej tożsamości).

W związku z faktem, że nie poświęcono szczególnie wiele uwagi turystyce związanej z mrocznymi filmami z dramatyczną fabułą (np. dotyczącą napięć politycznych), jest prawdopodobne, że złowrogie scenariusze, style i gatunki zagwarantują otoczenie, które będzie się łączyć z turystyką specjalnych zainteresowań i mroczną turystyką. W tym sensie negatywne fabuły i motywy, razem z brutalnymi gatunkami filmowymi, mogą wywołać chęć podróżowania do konkretnego regionu docelowego.

Co więcej, Loureiro i de Araujo (2015) przeanalizowali związek pomiędzy filmami a intencjami behawioralnymi i uznali go za znaczący dla mrocznej turystyki filmowej. Tzanelli (2016) zaś omówiła, jak scenografia i fabuła filmu kształtują fantazje wywołane przez turystykę filmową. Zapoczątkowana przez tę badaczkę dyskusja doprowadziła do postawienia pytań o autentyczność oraz wykorzystanie filmów w celu kreowania doświadczeń turystycznych. Przełomowa praca na temat miejsc dziedzictwa wykorzystywanych jako plenery filmowe powstała na temat Gry o tron (Bowyer, 2017). Filmy oraz seriale telewizyjne wytwarzają u widzów silną więź emocjonalną z przedstawionymi obszarami i zachowaniami aktorów, które zwiedzający i odpoczywający chcą naśladować i których pragną doświadczać (Beeton, 2016). Ponadto zagorzali fani filmów szukają w Internecie informacji o konkretnych plenerach filmowych, a wykreowany tam wizerunek danego miejsca może zwiększyć motywacje do odwiedzenia go w celach turystycznych (Spears, Josiam, Kinley, Pookulangara, 2013). W związku z tym autorzy niniejszej pracy uważaja że plenery filmowe mogą wzbudzić w odbiorcach chęć odwiedzenia danej lokalizacji, kształtować wizerunek tego miejsca oraz przywiązanie do niego, a co za tym idzie - za cel publikacji uznali zbadanie tego potencjalnie znaczącego powiązania. Co więcej, zdaniem autorów często występujące motywy uprawiania turystyki filmowej, jak np. chęć bycia oryginalnym, poczucie prestiż czy spełnienie fantazji (Macionis, Sparks, 2009), potencjalnie są związane również z mroczną turystyką filmową. 


\section{PROJEKT BADAWCZY}

Analiza ramowa (framing analysis) była już prowadzona w kontekście turystyki medialnej (Pan, Santos, Kim, 2016), w tym turystyki filmowej (zob. Pan, Kosicki, 1993; Pan, Tsai, Lee, 2011). Chociaż metoda ta nieczęsto jest wykorzystywana w studiach nad turystyka, jej potencjalne zastosowanie podczas badań dotyczących turystyki filmowej zostało rozważone i przedyskutowane (Pan, Kosicki, 1993; Pan, Tsai, Lee, 2011). Dlatego też teorię ramową zastosowano do oceny negatywnych fabuł filmowych w kontekście turystyki filmowej. Jednocześnie $\mathrm{w}$ niniejszej pracy wzięto pod uwagę teorię "zastosowań i gratyfikacji" w celu wyjaśnienia chęci poszukiwania nowości przez turystów. Została ona zastosowana w szczególności do oceny zamiaru zwiedzania mrocznych miejsc związanych z filmem Pengkhianatan G30S/PKI. Co więcej, materiał filmowy posłużył jako punkt wyjścia do refleksyjnej analizy tematycznej przy wykorzystaniu konstruktywnych teoretycznych perspektyw opisanych przez Braun i Clarke (2019).

\section{TEORIA RAMOWA}

Teoria ramowa została wprowadzona przez Goffmana (1974). Koncentrując się wokół organizacji indywidualnych doświadczeń, które ukazują się jako doświadczenia społeczne, analiza ramowa, która ma na celu podkreślenie konkretnego zjawiska jako bardziej znaczącego, jest często wykorzystywana w badaniach nad mediami (Fiske, 1983). W analizie ramowej kładzie się nacisk na konkretne wydarzenie w określonym kontekście, skupiając się na kwestiach uznawanych za niezbędne i ujawnionych przed opinią publiczną. Zasadniczo media kadrują pewne zjawiska, prezentują je i eksponują oraz ustalają porządek dzienny.

\section{TEORIA UŻYTKOWANIA I GRATYFIKACJI}

Teoria użytkowania i gratyfikacji została opisana we współczesnej literaturze dotyczącej komunikacji i rozpowszechnienia technologii, np. w opracowaniach na temat mediów społecznościowych i turystyki (Gan, Wang, 2015; Ho, See-To, 2018). Jednakże możliwości zastosowania tej teorii w kontekście turystyki filmowej wydają się ograniczone, pomimo że można ją wykorzystać do zbadania, jak negatywne fabuły filmowe i mroczne sceny motywują do uprawiania turystyki filmowej. Według tej teorii ludzie mogą aktywnie dążyć do zaspokajania swoich potrzeb poprzez wybór, a następnie użycie konkretnego środka przekazu, ukierunkowane na uzyskiwanie korzyści, co prowadzi do osiągnięcia celów poznawczych, afektywnych oraz behawioralnych (Katz, Blumer, Gurevitch, 1974).

W teorii użytkowania i gratyfikacji istotne jest, w jaki sposób ludzie wykorzystują media, a nie jak media wpływają na jednostki (Katz, Blumer, Gurevitch, 1974). To wyjaśnia stopień otwartości na nowe doświadczenia związane $\mathrm{z}$ chodzeniem do kina oraz czytaniem dla przyjemności. Jednocześnie potrzeba podglądania oraz osobowość wydają się powiązane z selektywną ekspozycją na media i treści oraz z czerpaniem z tego przyjemności (Krcmar, 2017). Dlatego też teoria użytkowania i gratyfikacji może być wykorzystywana przy próbie scharakteryzowania tanatoturystyki i turystyki specjalnych zainteresowań.

Ponadto w badaniach nad teorią użytkowania i korzyści przeniesiono środek ciężkości ze skutków wywołanych przez media na powody, dla których widzowie oglądają takie, a nie inne programy (Brown, Lauricella, Douai, Zaidi, 2012; Doyle, 2006; Rubin, 1993). Teoria ta jest odpowiednia do zgłębiania przyczyn, dla których jednostki decydują się obejrzeć film, aby zaspokoić potrzeby związane z turystyką filmową. Za odpowiednie do testowania satysfakcji uważane są: informacje lub ciekawostki, identyfikacja, interakcje społeczne oraz rozrywka. W nauce o komunikacji społecznej teorię użytkowania i gratyfikacji stosowano, by dowiedzieć się, dlaczego jednostki uważają dramaty kryminalne za interesujące. Wyniki poprzednich badań, prowadzonych nad motywacją do oglądania filmów, zaadaptowane z nauki o komunikacji społecznej, wskazywały na takie zmienne, jak wiek, płeć oraz częstotliwość oglądania filmów. Ponadto z tych studiów płynie również wniosek, że intensywne poszukiwanie wrażeń może skutkować pociagiem do programów telewizyjnych oraz treści internetowych cechujących się brutalnością (Krcmar, Greene, 1999; Slater, 2003), a także powoduje, że motywację do oglądania telewizji stanowią chęć zabicia czasu oraz eskapizm (Conway, Rubin, 1991). Podobnie Brown, Lauricella, Douai i Zaidi (2012) zasugerowali, że oglądanie telewizji może skutkować pełniejszym zaspokojeniem potrzeb, co z kolei stało się podstawą niniejszego badania w kontekście mrocznej turystyki filmowej.

Ponadto nie można nalegać na przyjęcie modeli badań kulturowych, zgodnie z którymi jednostronnie uznaje się znaczenie wpływu mediów na jednostkę, jednocześnie nie przyjmując do wiadomości, że użytkownicy mediów są zdolni do wykorzystania oraz interpretowania przekazywanych przez nie treści. W tym sensie kulturoznawstwo pogłębiło refleksyjną rolę konsumentów podczas doświadczania bądź konsumpcji konkretnej praktyki kulturowej (Costa, 2012b). Dlatego też jednostki nie zawsze dokonują interpretacji produktów medialnych zgodnie z interesami podmiotów gospodarczych. Według S. Halla jednostki odczytują także sprzeczności oraz negocjacje (Costa, 2012a). Co więcej, 
konsumpcja kultury destynacji turystycznej bądź doświadczenia filmowego stymulowana przez kino nie jest czymś wrodzonym ani naturalnym, dlatego też wpływ filmu na chęć zwiedzenia miejsca śmierci lub kaźni zależy od tego, czy jednostka przejawia krytyczne podejście wobec środków masowego przekazu, oraz od jej kapitału kulturowego.

Stafford i Stafford (1996) zwrócili uwagę na następujące rodzaje gratyfikacji: 1 ) związane $\mathrm{z}$ treścią (content) 2) związane z procesem (proces); oraz 3) społeczne (social). W szczególności pierwszy rodzaj odnosi się do samego przekazu, z kolei drugi łączy się z procesem komunikacji. Zadowolenie $\mathrm{z}$ treści odnosi się do spełnienia oczekiwań informacyjnych, na które składają się takie działania, jak poszukiwanie informacji i dzielenie się nimi. Z kolei satysfakcja społeczna odnosi się do komunikacji z innymi ludźmi. Zadowolenie z treści uznano za najwłaściwsze dla niniejszego badania ze względu na jego zastosowanie w analizie ramowej. Co więcej, wiąże się to z drugim celem, który koncentruje się na tym, jak oglądanie filmów wpływa na zachowania turystów filmowych, i stanowi bazę dla konceptualizacji, jak negatywne fabuły i sceny filmowe wpisują się w turystykę filmową i mroczną. W tym kontekście istnieje duże prawdopodobieństwo, że teoria użytkowania i gratyfikacji potwierdzi szczególne zainteresowanie turystyka, co z kolei zasugeruje tendencje turystów do poszukiwania nowości w czasie zwiedzania ciekawych miejsc.

\section{REFLEKSYJNA ANALIZA TEMATYCZNA}

W badaniach nad turystyką zachęca się do wykorzystywania analizy tematycznej (Walters, 2016), refleksyjna analiza tematyczna zaś ma na celu zbadanie znaczenia i konstrukcji sytuacji społecznych poprzez określone tematy (Braun, Clarke, 2019). Oprogramowanie komputerowe służące do przeprowadzenia jakościowej analizy danych nie zostało użyte ze względu na wagę głębokiej refleksji w analizie tematycznej oraz znaczenie subiektywności badacza w paradygmacie jakościowym (Braun, Clarke, 2019). Zamiast tego zdecydowano się zatem na objerzenie filmu Pengkhianatan G30S/PKI. Przedmiotem analizy była konstrukcja samej produkcji o ponurej tematyce, natomiast mroczne miejsca historyczne przedstawione $\mathrm{w}$ negatywnej fabule filmowej zostały zbadane zgodnie $\mathrm{z}$ jej podstawową koncepcją oraz współdzielonym znaczeniami, w celu dokonania dogłębnej analizy zjawiska w kontekście prawdziwego życia (Yin, 2013).

Refleksyjność w analizie tematycznej sugeruje kluczową rolę, jaką powinien odgrywać badacz generujący odpowiednie tematy oraz główne społeczne znaczenie badanych zagadnień (Braun, Clarke, 2019).
Zastosowanie takiego podejścia ma na celu identyfikację motywów w kontekście społeczno-kulturowym oraz ideologicznym. Procedury analizy tematycznej odzwierciedlają paradygmat jakościowy oraz skupienie na subiektywności badacza, nie zaś na podejściu teoretycznym (Braun, Clarke, 2019). Subiektywizm badacza obejmuje analizę opartą na organicznych i rekurencyjnych procesach kodowania, a także na znaczeniu głębokiej refleksji i zaangażowania w pracę związaną z danymi (Braun, Clarke, 2019). Subiektywność „,kodującego", która obejmuje teoretyczną wrażliwość, zainteresowania oraz doświadczenia, działa w analizie tematycznej jak filtr. Z tego względu wyniki analizy to raczej ciągłe wprowadzanie poprawek niż ustalenie ostatecznej wersji (McAllum, Fox, Simpson, Unson, 2019).

Turystyka filmowa o mrocznych motywach oraz mroczne miejsca historyczne ukazane w filmach o negatywnej fabule rozwinęły się z dawnych studiów przygotowanych z wykorzystaniem metody dedukcyjnej, która również była brana pod uwagę jako możliwa do zastosowania przy prowadzeniu badań opisanych w niniejszym artykule. Skupiając się na centralnej koncepcji, opartej na znaczeniu turystyki filmowej o mrocznych motywach i mrocznych miejsc historycznych w negatywnych fabułach filmowych, wygenerowano tematy odpowiednie dla mrocznej turystyki filmowej w odniesieniu do intencji zwiedzania. W tym przypadku analiza tematyczna jednoznacznie wyznaczyła kroki podejmowane przez badaczy jako filtr podczas zaznajamiania się z atrybutami filmu, kodowaniem, poprawkami oraz generowaniem motywów. Przeanalizowane atrybuty filmu obejmują plener, scenerię, krajobraz, pogodę, pochodzenie kulturowe, pochodzenie społeczne, pochodzenie działania, obsadę, bohaterów, celebrytów i gwiazdy, fabułę, tematykę oraz gatunek.

\section{WYNIKI BADAŃ}

Jak wspomniano w podrozdziale dotyczącym przeglądu literatury (zob. O'Connor, Flanagan, Gilbert, 2008), uzyskane wyniki badań mogą zostać wykorzystane w celu sporządzenia schematu charakterystycznej fabuły oraz marki antykomunistycznych muzeów i miejsc historycznych, takich jak Lubang Buaya i Kesaktian Pancasila. Ogólnie wyniki badań wskazują że oglądanie filmów zaspokaja potrzeby, wzbudza motywy, które wpływają na sposób korzystania z mediów, jak również wywołuje efekty kognitywne, afektywne oraz behawioralne. Oglądanie negatywnych fabuł i scen filmowych wpływa na podejmowanie działań przez turystów filmowych; fabuły i sceny te służą jako czynniki motywujące do uprawiania turystyki filmowej. W związku z tym niniejsze badanie sugeruje, by na 
przykładzie filmu Pengkhianatan G30S/PKI postrzegać je jako warstwy turystyki filmowej i mrocznej, podczas gdy antykomunistyczne muzea i miejsca historyczne w Indonezji są warstwą czerwonej turystyki w południowo-wschodniej Azji.

$\mathrm{Z}$ analizy wynika, że główna, oparta na znaczeniu koncepcja Pengkhianatan G30S/PKI obejmuje mroczne motywy, negatywną fabułę uwzględniającą kontekst polityczny oraz tragedię, jaka rozegrała się $\mathrm{w}$ historii narodu. Negatywnie przedstawione plenery filmowe przyciągają turystów interesujących się mroczną turystyką i wzbogacają warstwy zarówno turystyki filmowej, jak i czerwonej turystyki. Poza tym powiązanie historii narodu z czerwoną turystyką filmową oraz turystyką edukacyjną można określić jako mroczną turystykę edukacyjną lub - innymi słowy - zwiedzanie nieprzyjaznych plenerów filmowych, które zawierają konkretne elementy fabuły przypisywane mrokom historii narodowej, przy skupieniu na kontekście politycznym oraz tragedii narodowej. Wykracza to poza dyskurs polityczny i skupia się na przyjęciu turystów poszukających nowości. Jak zauważają Costa i Korstanje (2016), owo poszukiwanie atrakcji może w rzeczywistości ujawnić pełne szacunku, ale krytyczne podejście do przeszłości lub wręcz przeciwnie - postawę wyobcowania, a nawet dostarczyć przykładów zachowań sadystycznych.

Jak przedstawiono $\mathrm{w}$ tab. 1 i 2, motywy wyodrębnione na podstawie Pengkhianatan G30S/PKI można wykorzystać jako atrybuty mrocznej turystyki filmowej. W tym przypadku mroczne miejsca historyczne ukazane w negatywnej fabule filmowej znajdują się w Lubang Buaya i Kesaktian Pancasila, gdzie powstały antykomunistyczne muzea oraz miejsca historyczne. Jednocześnie działania Ruchu 30 Września, w których bardzo ważną rolę odegrała ideologia antykomunistyczna, są uznawane za tragedię w historii Indonezji, skutkującą śmiercią sześciu generałów. Wspomniane atrybuty mrocznej turystyki filmowej, szczególnie realia polityczne, tragedia, która rozegrała się 30 września 1965 r., oraz związane z nimi wątki, można uznać za elementy mrocznej turystyki edukacyjnej.

Fascynacja śmiercią polityków, VIP-ów, sław oraz innych osobistości życia publicznego jest nie tylko podsycana przez media, ale także wykorzystywana przez organy turystyczne i władze jako element turystyki medialnej. Tragiczne wydarzenia sprawiaja, że miejsce czyjejś śmierci staje się potencjalną atrakcją turystyczną. Nie dziwi więc fakt, że - jak sugeruje Beeton (2016) - turystyka filmowa jako tło akcji i prezentowanego wrogiego otoczenia zawiera w sobie element przywiązania emocjonalnego. W pewnym sensie tego rodzaju podróże mają być autentycznymi przeżyciami, które określa się powszechnie mianem reality tourism oraz vacation dedication (Ring, Yanamandram, Gretzel, Dolnicar, 2019). Z dużym prawdopodobieństwem reality tourism będzie obejmować wycieczki kulturowe oparte na altruizmie, w tym zwiedzanie makabrycznych miejsc

Tabela 1. Proces kodowania w mrocznej turystyce filmowej

\begin{tabular}{|l|l|l|}
\hline \multicolumn{1}{|c|}{$\begin{array}{l}\text { Znaczenie jednostek } \\
\text { z danych nieprzetworzonych }\end{array}$} & Kody pierwszego poziomu & \multicolumn{1}{c|}{ Kategoria tematów } \\
\hline $\begin{array}{l}\text { Komunistyczny zamach } \\
\text { stanu w } 1965 \mathrm{r} .\end{array}$ & $\begin{array}{l}\text { Fabuły związane } \\
\text { z realiami politycznymi }\end{array}$ & $\begin{array}{l}\text { Negatywne fabuły filmowe } \\
\text { Ramowanie czerwonej turystyki dla potrzeb mrocznych miejsc }\end{array}$ \\
\hline Ruch 30 Września & Tragedia & Historia narodu \\
\hline $\begin{array}{l}\text { Lubang Buaya i Kesaktian } \\
\text { Pancasila }\end{array}$ & $\begin{array}{l}\text { Mroczne miejsca, } \\
\text { w tym historyczne }\end{array}$ & Antykomunistyczne muzea i miejsca historyczne \\
\hline $\begin{array}{l}\text { Siedmiu porwanych } \\
\text { i zamordowanych generałów }\end{array}$ & $\begin{array}{l}\text { Fabuły } \\
\text { Plenery filmowe }\end{array}$ & $\begin{array}{l}\text { Mroczna turystyka edukacyjna } \\
\text { Turystyka filmowa lub medialna }\end{array}$ \\
\hline
\end{tabular}

Źródło: opracowanie własne.

Tabela 2. Definiowanie tematów dla potrzeb mrocznej turystyki filmowej

\begin{tabular}{|l|l|}
\hline \multicolumn{1}{|c|}{ Tematy } & \multicolumn{1}{c|}{ Opis tematów } \\
\hline $\begin{array}{l}\text { Negatywne fabuły filmowe } \\
\text { Ramowanie czerwonej turystyki dla potrzeb } \\
\text { mrocznych miejsc }\end{array}$ & $\begin{array}{l}\text { Konteksty ideologiczne, sadyzm, masowe mordy, zabójstwo sześciu } \\
\text { generałów i członków ich rodzin }\end{array}$ \\
\hline Historia narodu & Program polityczny i ruch antykomunistyczny \\
\hline Antykomunistyczne muzea i miejsca historyczne & Sława bohaterów, status quo i początek nowej ery w Indonezji \\
\hline $\begin{array}{l}\text { Mroczna turystyka edukacyjna } \\
\text { Turystyka filmowa lub medialna }\end{array}$ & $\begin{array}{l}\text { Fascynacja śmiercią sześciu generałów, mroczna historia, tragedia narodu } \\
\text { w mrocznych miejscach, możliwość poznania mrocznych miejsc historycz- } \\
\text { nych dzięki mrocznej turystyce filmowej }\end{array}$ \\
\hline
\end{tabular}

Źródło: opracowanie własne. 
(Foley, Lennon, 1996; Freire-Medeiros, 2009). W mrocznej turystyce filmowej negatywne fabuły, motywy oraz gatunki stanowią główne przedstawione towary, które również mogą zostać włączone do reality tours, a także potwierdzają powody, dla których jednostki decydują się na objerzenie filmu $w$ ramach zaspokajania swoich potrzeb. Film G30S/PKI ogniskuje się wokół napięcia politycznego pomiędzy ruchem komunistycznym a historią narodowa, co podważa zasadność zwiedzania ukazanych w filmie mrocznych miejsc, tj. Muzeum Lubang Buaya oraz Muzeum Kesaktian Pancasila. Teoria ramowa wykorzystana w niniejszym opracowaniu pozwala na identyfikację negatywnej fabuły w kontekście turystyki filmowej oraz sposobów dokonania ramowania mrocznych miejsc $w$ odniesieniu do historii komunizmu. Komunizm w Indonezji został ujęty w ramy poprzez uwzględnienie miejsc historycznych przedstawionych w filmie oraz innych znaczących punktów orientacyjnych miasta, takich jak Patung Tugu Tani.

Problemy ujawnione $\mathrm{w}$ konkretnych plenerach filmowych być może nie zwiększą chęci oglądających, by odwiedzić te miejsca, a nawet mogą wywołać odwrotny skutek. Przedstawione w negatywny sposób miejsca lub negatywne wątki filmowe mogą zniechęcić widzów do odwiedzenia ich. Jak nadmieniają w swojej pracy Pan i Kosicki (1993), uwzględniając te aspekty, można także wyjaśnić zawiłości wydarzeń historycznych na zasadzie efektu mediacji filmu w procesie ramowania historii narodowej. Stanowi to wytłumaczenie dla zdobywającego coraz większą popularność fenomenu czerwonej turystyki filmowej wraz z obecną najnowszą mroczną turystyka, która pobudza pragnienie turysty, by odwiedzić makabryczne miejsce, gdzie dokonano masowego mordu.

Zachowania związane $\mathrm{z}$ oglądaniem filmów są wrażliwe i napędzane przez media, a taka gratyfikacja zaspokaja pragnienie poszukiwania nowości $\mathrm{w}$ turystyce. Wyjaśnia również, w jaki sposób historia jest konstruowana przez władzę i autorytet, a filmy są wykorzystywane do rozwijania historii narodowej i miejsc turystycznych przedstawionych na filmach.

Nowe formy konsumpcji obejmujące tragedię, śmierć oraz katastrofę stały się towarem wymiennym i otworzyły możliwość przeżywania na nowo doświadczeń przedstawionych w filmach, które dotyczą aspektu krytycznego myślenia $w$ turystyce specjalnych zainteresowań i tanatoturystyce. $\mathrm{W}$ ten sposób zwiedzanie przedstawionych $\mathrm{w}$ filmach miejsc, $\mathrm{w}$ których ktoś poległ bohaterską śmiercia, i ponowne przeżywanie zaprezentowanych doświadczeń pobudza krytyczne myślenie w obrębie turystyki specjalnych zainteresowań. Takie działanie pozwala mrocznym turystom zaspokoić ich pragnienie kontemplacji i autorefleksji. W związanych z tym zagadnieniem badaniach mroczną turystykę określa się jako wzmacniająca ego, gdyż przyglądanie się tragedii innych wywołuje poczucie uprzywi- lejowania. Podobnie jak filmy oparte na mrocznych bądź negatywnych fabułach potencjalnie napędzają zachowania związane ze zwiedzaniem, skonstruowana historia narodowa może wzbogacić warstwy turystyki specjalnych zainteresowań oraz turystyki mrocznej.

\section{WNIOSKI I ZALECENIA DLA PRZYSZKYCH BADAŃ}

Przedstawione w niniejszej pracy studium przypadku uwydatnia punkty styczne pomiędzy turystyką śmierci a turystyką filmową i kładzie podwaliny pod dogłębną dyskusję filozoficzną na temat sposobów pobudzania turystyki za pomocą filmów zawierających mroczne motywy wywodzące się z tła politycznego narodu. Dostarczyło ono także dowodów na to, że interesariusze turystyki filmowej powinni podkreślać piękno naturalnych scenerii, krajobrazów i miejsc dziedzictwa, które są czynnikami napędowymi rozwoju turystyki filmowej lub jej tłem, natomiast mroczne motywy odnoszące się do kontekstu politycznego, masowych mordów i zabójstw z przyczyn politycznych służą rozwojowi niszowych rynków turystycznych oraz turystyki specjalnych zainteresowań. Poza tym z przeprowadzonych badań wynika, że istnieją turyści poszukujący nowości oraz że "poszukiwacze śmierci" i tanatoturyści zgłębiają ,jjasną stronę" mroku. Negatywne fabuły filmowe oraz ramy polityczne w kontekście turystyki filmowej są ukierunkowane na odbiorców. Wydaje się, że ukazanie heroicznej śmierci w połączeniu z tłem politycznym można uznać za zjawisko kreujące wartości współdzielone przez turystów. Poszukiwanie „końca” może prowadzić mrocznych turystów do pogłębienia duchowości.

W związku z tym zaleca się, by w przyszłych badaniach były brane pod uwagę:

- obecne zachowania związane z oglądaniem produkcji filmowych oraz negatywne skojarzenia $z$ fabułami filmów politycznych jako predyktory zachowań turystów filmowych i widzów,

- motywacje do uprawiania turystyki filmowej,

- zachowania związane z podróżowaniem,

- profile demograficzne mrocznych turystów filmowych.

Powinny również zostać zbadane skutki motywacji „konsumpcyjnej” odpowiadającej za oglądanie filmów, mające na celu uzyskanie gratyfikacji (zdobywanie informacji bądź zaspokajanie ciekawości, identyfikacja, interakcje społeczne oraz rozrywka), rozpatrywane przez pryzmat wieku, płci i częstotliwości oglądania, tak by można było wykazać, jak owe zmienne wpływają na wizyty czerwonych (bądź mrocznych) turystów w miejscach historycznych i zabytkowych, takich jak antykomunistyczne muzea. Poza tym należałoby 
przeprowadzić badania nad wpływem vacation dedication na częstotliwość odwiedzin w antykomunistycznych muzeach, takich jak Muzeum Lubang Buaya i Muzeum Kesaktian Pancasila.

W odniesieniu do trzech pytań postawionych w niniejszej pracy stwierdzono, że film może wyzwalać popyt turystyczny, jednak nie można dowieść pozytywnej zależności przyczynowo-skutkowej. Popyt turystyczny jest zjawiskiem heterogenicznym, dynamicznym i silnie rozwarstwionym z emocjonalnego punktu widzenia. W badaniach zwrócono uwagę na intensywny i kreatywny związek między popytem turystycznym a miejscami, w których kręcone są filmy. Niektórzy badacze wykazali jednak ograniczenie takiego wpływu. Co się tyczy kwestii antykomunizmu budzącego w ludziach szczególne zainteresowanie mroczną turystyka, autorzy wnioskuja że wraz z politycznym odrodzeniem skrajnej prawicy w niektórych krajach paranoiczny strach przed socjalizmem może być czynnikiem motywującym do odwiedzenia antykomunistycznego muzeum w Indonezji. Na koniec należy stwierdzić, że nie jest możliwe wywnioskowanie, czy w turystyce da się zauważyć krytyczne myślenie, skoro przedstawiony antykomunistyczny kontekst filmowy w znacznie większym stopniu obejmuje ultranacjonalistyczne i skrajne ideologie niż myśli libertariańskie i wyzwolone.

\section{PRZYPISY}

\footnotetext{
${ }^{1}$ Pojawiające się $\mathrm{w}$ tekście angielskim pojęcie political framing w polskojęzycznej wersji artykułu zostało przetłumaczone jako: kontekst polityczny, tło polityczne lub realia polityczne. Terminy te są tu traktowane jako synonimy.

${ }^{2}$ Użyty w wersji anglojęzycznej termin national history w tekście polskim został przetłumaczony jako polityka historyczna.
}

\section{REFERENCES/BIBLIOGRAFIA}

30 September Movement (2020). Retrieved from: https:// en.wikipedia.org/wiki/30_September_Movement (12.06.2019).

Adams, K.M. (1998). Domestic tourism and nation-building in South Sulawesi. Indonesia and Malay World, 26 (75), 77-96. https://doi.org/10.1080/13639819808729913

Adams, K.M. (2016). Tourism and ethnicity in insular Southeast Asia: Eating, praying, loving and beyond. Asian Journal of Tourism Research, 1 (1), 1-28. https://doi.org/10.12982/AJTR.2016.0001

Azevedo, A. (2017). Lighthouse tourism: Is there a "dark" side? International Journal of Tourism Cities, 4 (1), 54-67. https://doi. org/10.1108/IJTC-03-2017-0019

Beeton, S. (2016). Film-induced tourism. Bristol-Buffalo-Toronto: Channel View Publications. https://doi.org/10.21832/9781845415853

Bencivenga, A., Chiarullo, L., Colangelo, D. (2015). Film tourism in Basilicata. Almatourism - Journal of Tourism, Culture and Territorial Development, 6 (4), 241-260.

Bolan, P., Boy, S., Bell, J. (2011). „We've seen it in the movies, let's see if it's true". Authenticity and displacement in film-induced tourism. Worldwide Hospitality and Tourism Themes, 3 (2), 102-116. https://doi.org/10.1108/17554211111122970

Bowyer, E. (2017). The Influence of heritage sites as filming locations on tourists' decisions to visit sites and their perceptions of them. Case study: „Game of Thrones”. Coactivity: Philosophy, Communication / Santalka: Filosofija, Komunikacija, 25 (1), 110-122. https://doi.org/10.3846/cpc.2017.286

Braun, V., Clarke, V. (2019). Reflecting on reflexive thematic analysis. Qualitative Research in Sport Exercise and Health, 11 (4), 589-597. https://doi.org/10.1080/2159676X.2019.1628806

Brown, D., Lauricella, S., Douai, A., Zaidi, A. (2012). Consuming television crime drama: A uses and gratifications approach. American Communication Journal, 14 (1), 47-60.

Cardoso, L., Estevão, C., Fernandes, C., Alves, H. (2017). Film induced tourism: A systematic literature review. Tourism E Management Studies, 13 (3), 23-30. https://doi.org/10.18089/ tms.2017.13303

Çoban, F. (2018a). Political Reflections on dark tourism: The case of Turkey. In: M. Korstanje, B. George, Virtual traumascapes and exploring the roots of dark tourism (pp. 99-125). Hershey PA: IGI Global. https://doi.org/10.4018/978-1-5225-2750-3.ch006

Çoban, F. (2018b). Dark tourism as a form of governmentality of fear. In: M. Korstanje, B. George, Virtual traumascapes and exploring the roots of dark tourism (pp. 126-149). Hershey PA: IGI Global. https://doi.org/10.4018/978-1-5225-2750-3.ch007

Conway, J.C., Rubin, A.M. (1991). Psychological predictors of television viewing motivation. Communication Research, 18 (4), 443-463. https://doi.org/10.1177/009365091018004001

Costa, J.H. (2012a). Stuart Hall e o modelo „encoding and decoding": Por uma compreensão plural da recepção. Revista Espaço Acadêmico, 12 (136), 111-121.

Costa, J.H. (2012b). Os estudos culturais em debate: Um convite às obras de Richard Hoggart, Raymond Williams \& E.P. Thompson. Acta Scientiarum. Human and Social Sciences, 34 (2), 159-168. https://doi.org/10.4025/actascihumansoc.v34i2.17706

Costa, J.H. (2013). A atualidade da discussão sobre a indústria cultural em Theodor W. Adorno. Trans/Form/Ação, 36 (2), 135-154. https://doi.org/10.1590/S0101-31732013000200009

Costa, J.H., Korstanje, M.E. (2016). Nuevos conceptos, nuevas realidades: Revisando el rol de la belleza en la formación del turismo oscuro. Revista Turismo em Análise, 27 (3), 696-713. https://doi.org/10.11606/issn.1984-4867.v27i3p696-713

Croy, W.G. (2004). The Lord of the Ring, New Zealand and tourism: Image building with film. Monash University, Faculty of Business \& Economics.

Curtin, S. (2010). The self-presentation and self-development of serious wildlife tourists. International Journal of Tourism Research, 12 (1), 17-33. https://doi.org/10.1002/jtr.734

Dolezal, C., Trupp, A. (2015). Tourism and development in Southeast Asia. ASEAS - Austrian Journal of South-East Asian Studies, 8 (2), 117-124.

Doyle, A. (2006). How not to think about crime in the media. Canadian Journal of Criminology and Criminal Justice, 48 (6), 867-885. https://doi.org/10.3138/cjccj.48.6.867

Festiani, S., Azizah, N., Rostiyani, Y. (2012). Lubang Buaya, the forgotten museum. Retrieved from: https://republika.co.id/berita/ en/travelling-2/12/02/11/lz8646-lubang-buaya-the-forgotten-museum (12.06.2018).

Fiske, J. (1983). The discourses of TV quiz shows or, school + luck = success + sex. Communication Studies, 34 (3), 139-150. https:// doi.org/10.1080/10510978309368135

Foley, M., Lennon, J.J. (1996). JFK and dark tourism: A fascination with assassination. International Journal of Heritage Studies, 2 (4), 198-211. https://doi.org/10.1080/13527259608722175

Freire-Medeiros, B. (2009). The favela and its touristic transits. Geoforum, 40 (4), 580-588. https://doi.org/10.1016/j.geoforum.2008.10.007 
Gan, C., Wang, W. (2015). Uses and gratifications of social media: A comparison of microblog and WeChat. Journal of Systems and Information Technology, 17 (4), 351-363. https://doi.org/10.1108/ JSIT-06-2015-0052

Goffman, E. (1974). Frame analysis: An essay on the organization of experience. Cambridge, MA, US: Harvard University Press.

Handayani, B. (2017). Masih relevankah berkunjung ke Museum Lubang Buaya? Retrieved from: http://www.industry.co.id/ read/7124/masih-relevankah-berkunjung-ke-museum-lubang-buaya\#.WPY3foMtR18.facebook (30.06.2018).

Handayani, B., Korstanje, M.E. (2017). Gazing at death: Dark tourism as an emergent horizon of research. New York: Nova Science Publishers.

Hao, X., Ryan, C. (2013). Interpretation, film language and tourist destinations: A case study of Hibiscus Town, China. Annals of Tourism Research, 42, 334-358. https://doi.org/10.1016/j. annals.2013.02.016

Ho, K.K., See-To, E.W. (2018). The impact of the uses and gratifications of tourist attraction fan page. Internet Research, 28 (3), 587-603. https://doi.org/10.1108/IntR-04-2017-0175

Ikhwan, H., Yulianto, V.I., Parahita, G.D. (2019). The contestation of social memory in the new media: A case study of the 1965 killings in Indonesia. Austrian Journal of South-East Asian Studies, 12 (1), 3-16.

Ivanova, M., Buda, D.M. (2020). Thinking rhizomatically about communist heritage tourism. Annals of Tourism Research, 84, 103000. https://doi.org/10.1016/j.annals.2020.103000

Jordan, P. (2014). Nation branding: A tool for nationalism. Journal of Baltic Studies, 45, 283-303. https://doi.org/10.1080/0162977 8.2013.860609

Kami, M.I. (2017). Tentang Tugu Tani yang Didemo karena Dianggap Simbol Komunis. Detik News. Retrieved from: https://news.detik.com/berita/d-3663965/tentang-tugu-tani-yang-didemo-karena-dianggap-simbol-komunis (25.06.2018).

Katz, E., Blumer, J.G., Gurevitch, M. (1974). The uses of mass communications: Current perspectives on gratifications research. In: W. Davison, F. Yu (eds), Mass communication research: Major issues and future directions (pp. 19-32). Beverly Hills: Sage Publishing.

Kim, S., Reijnders, S. (2018). Asia on my mind: Understanding film tourism in Asia. In: S. Kim, S. Reijnders, Film Tourism in Asia (pp. 1-18). Singapur: Springer. https://doi. org/10.1007/978-981-10-5909-4_1

Krcmar, M. (2017). Uses and gratifications: Basic concepts. The International Encyclopedia of Media Effects, 1-13. https://doi. org/10.1002/9781118783764.wbieme0045

Krcmar, M., Greene, K. (1999). Predicting exposure to and use of violent television. Journal of Communication, 49 (3), 25-45. https://doi.org/10.1111/j.1460-2466.1999.tb02803.x

kumparanNEWS (2017). Sejarawan LIPI: Tugu Tani Bukan Simbol Komunisme. Retrieved from: https://kumparan.com/@kumparannews/sejarawan-lipi-tugu-tani-bukan-simbol-komunisme (25.06.2018).

Lennon, J. (2018). Kanchanaburi and the Thai-Burma railway: Disputed narratives in the interpretation of war. International Journal of Tourism Cities, 4 (1), 140-155. https://doi.org/10.1108/ IJTC-06-2017-0033

Li, Y., Hu, Z.Y., Zhang, C.Z. (2010). Red tourism: Sustaining communist identity in a rapidly changing China. Journal of Tourism and Cultural Change, 8 (1-2), 101-119. https://doi.org/10.1080/ 14766825.2010.493939

Loureiro, S.M.C., de Araujo, A.B. (2015). Negative film plot and tourists image and intentions: The case of "City of God". Journal of Travel \& Tourism Marketing, 32 (4), 352-365. https:// doi.org/10.1080/10548408.2014.896769
Macionis, N. (2004). Understanding the film-induced tourist. In: International tourism and media conference proceedings. Vol. 4 (pp. 86-97). Melbourn: Tourism Research Unit, Monash University.

Macionis, N., Sparks, B. (2009). Film-induced tourism: An incidental experience. Tourism Review International, 13 (2), 93-101. https://doi.org/10.3727/154427209789604598

McAllum, K., Fox, S., Simpson, M., Unson, C. (2019). A comparative tale of two methods: How thematic and narrative analyses author the data story differently. Communication Research and Practice, 5 (4), 358-375. https://doi.org/10.1080/22041451.2019.1677068

Miles, W.F. (2002). Auschwitz: Museum interpretation and darker tourism. Annals of Tourism Research, 29 (4), 1175-1178. https:// doi.org/10.1016/S0160-7383(02)00054-3

O'Connor, N., Flanagan, S., Gilbert, D. (2008). The integration of film-induced tourism and destination branding in Yorkshire, UK. International Journal of Tourism Research, 10 (5), 423-437. https://doi.org/10.1002/jtr.676

Pan, S., Tsai, H., Lee, J. (2011). Framing New Zealand: Understanding tourism TV commercials. Tourism Management, 32 (3), 596-603. https://doi.org/10.1016/j.tourman.2010.05.009

Pan, Z., Kosicki, G.M. (1993). Framing analysis: An approach to news discourse. Political Communication, 10 (1), 55-75. https:// doi.org/10.1080/10584609.1993.9962963

Reijnders, S. (2016). Stories that move: Fiction, imagination, tourism. European Journal of Cultural Studies, 19 (6), 672-689. https://doi.org/10.1177/1367549415597922

Ring, A., Yanamandram, V., Gretzel, U., Dolnicar, S. (2019). Conceptualizing vacation dedication. Current Issues in Tourism, 23 (14), 1732-1736. https://doi.org/10.1080/13683500.2019.1678572

Rubin, A.M. (1993). Audience, activity, and media use. Communication Monographs, 60 (1), 98-105. https://doi. org $/ 10.1080 / 03637759309376300$

Sabre, C. (2017). Between literary tourism and contents tourism: Marcel Proust and his Madeleine as a tourist attraction. International Journal of Contents Tourism, 2, 1-11.

Seaton, P.A., Yamamura, T. (2018). Japanese popular culture and contents tourism. London: Routledge. https://doi. org/10.4324/9781315528694

Slater, M.D. (2003). Alienation, aggression and sensation seeking as predictors of adolescent use of violent film, computer and website content. Journal of Communication, 53 (1), 105-121. https://doi.org/10.1111/j.1460-2466.2003.tb03008.x

Spears, D.L., Josiam, B.M., Kinley, T., Pookulangara, S. (2013). Tourist see tourist do: The influence of Hollywood movies and television on tourism motivation and activity behavior. Hospitality Review, 30 (1), 4.

Stafford, M.R., Stafford, T.F. (1996). Mechanical commercial avoidance: A uses and gratifications perspective. Journal of Current Issues \& Research in Advertising, 18 (2), 27-38. https://doi.org/ 10.1080/10641734.1996.10505049

Strange, C., Kempa, M. (2003). Shades of dark tourism: Alcatraz and Robben Island. Annals of Tourism Research, 30 (2), 386-405. https://doi.org/10.1016/S0160-7383(02)00102-0

Tüzünkan, D. (2017). The relationship between innovation and tourism: The case of smart tourism. International Journal of Applied Engineering Research, 12 (23), 13861-13867.

Tzanelli, R. (2016). Thanatourism and cinematic representations of risk: Screening the end of tourism. Vol. 176. London: Routledge. https://doi.org/10.4324/9781315624105

Viganò, G. (2003). Enogastronomy: A path towards the discovery of the local culture. Mediolan: Univerità Bocconi.

Walters, T. (2016). Using thematic analysis in tourism research. Tourism Analysis, 21 (1), 107-116. https://doi.org/10.3727/1083 54216X14537459509017

Yin, R.K. (2013). Case study research: Design and methods. Thousand Oaks, CA: Sage Publications. 